reserves are exhausted. Thus, it is concluded that the pathways of lipid mobilisation in fern spores are identical to those in higher plant seeds (Gemmrich 1981).

With regard to the regulation of lipid metabolism, the involvement of at least three control mechanisms becomes evident: (1) enzymes present in the dry spore as remnants of sporogenesis regain their activity upon rehydration. These are the enzymes of lipid synthesis and mobilisation; (2) enzymes active during the imbibition phase may be translated from stable mRNA (Fechner and Schraudolf 1985); (3) by the induction stimulus, a co-ordinated and enhanced protein synthesis via transcription is initiated, resulting in germination. These control mechanisms are presently being studied at a molecular level.

Gemmrich, A. R. 1977. Fatty acid composition of fern spore lipids. Phytochemistry 16, 1044-1046.

— 1979. Lipid synthesis in imbibed spores of the fern Anemia phyllitidis. Z. PflPhysiol. 91, 317-324.

- 1981. Ultrastructural and enzymatic studies on the development of microbodies in germinating spores of the fern Anemia phyllitidis. Z. PflPhysiol. 102, 69-80.

Fechner, A. and Schraudolf, H. 1985. Molecular biological events of imbibing and germinating spores of Anemia phyllitidis L.Sw. Proc. Roy. Soc. Edinb. 86B, 449-450.

\title{
In vitro spore germination in Cyathea spinulosa
}

\section{A. Padhya and S. Kaul}

Department of Botany, The M.S. University of Baroda, Baroda, India

There are very few reports about spore germination in members of the Cyatheaceae, possibly due to their restricted distribution. In spite of high dispersibility of the Cyatheous spores, these members are isolated due to their adaptation to small environmental areas not duplicated within the range of dispersal. Such endemics are highly vulnerable to extinction if there is a significant climate change (Tryon and Gastony 1975).

The optimal conditions for the synchronous spore germination of Cyathea spinulosa in axenic cultures have been investigated.

Fertile fronds of Cyathea spinulosa growing at Pachmarhi Hills of Madhya Pradesh were collected in the month of January. The spores obtained from this collection were mature and viable and resulted in synchronous germination when provided with the requisite cultural conditions. After pre-soaking for 24 hours to induce complete imbibition, the spores became photosensitive. Surface sterilised spores grown in modified Knudson's liquid medium ( $\mathrm{pH} 4.5)$ germinated synchronously after exposure to 10 hours of light followed by 14 hours of dark period at $22 \pm 2{ }^{\circ} \mathrm{C}$.

These spores contain large quantities of lipids as reserve storage material. Imbibed spores tested with sudan IV gave positive results, confirming the presence of lipids. Extraction with organic solvents revealed that $40 \%$ of the weight of dry spores was lipid. During the germination process, the first cell to be differentiated was the protonemal cell. By the time the filament became two- to three-celled, the basal cell showed a decrease in lipid content, indicating that lipid was used as an energy source during germination.

Tryon, R. M. and Gastony, G. S. 1975. The biogeography of endemism in the Cyatheaceae. Fern Gaz. 11, 73-79. 